\title{
2
}

\section{Covid-Spiracy: Old Wine in New Barrels?}

\author{
Peter Achterberg
}

How to make sense of the current COVID-19 crisis? While many people rely on official statements made by governments, scientific institutions, and experts for answering this question, others do not. Recently, the Dutch newspaper NRC Handelsblad ${ }^{1}$ reported on people who adhere to the conspirational theory that the current COVID-19 crisis is linked to the introduction of $5 \mathrm{G}$ technology. These people point, for example, to so-called $5 \mathrm{G}$ experiments in the province of Wuhan, China, where the current COVID-19 crisis started in 2019. The "covid-spiracy" theory suggests that behind the societal curtains, elites are trying to deal with the problem of overpopulation by means of introducing 5G and blaming COVID-19 for the negative side effects. On Facebook and Twitter, people are actively discussing these theories with increasing momentum. And, inspired by theories on the adverse effects of $5 \mathrm{G}$, people have tried to destroy $5 \mathrm{G}$ technology and hinder the spread of this technology in the Netherlands.

Meanwhile, the mainstream media (MSM) have been directing their attention to this newly developing phenomenon-the Volkskrant, NRC

\footnotetext{
${ }^{1}$ https://www.nrc.nl/nieuws/2020/04/19/nana-denkt-dat-de-overheid-ons-uitdunt-met-5g-tijdenscorona-a3997217
}

P. Achterberg ( $\bowtie)$

Department of Sociology, Tilburg School of Social and Behavioral Sciences, Tilburg, The Netherlands e-mail: P.Achterberg@tilburguniversity.edu

E. Aarts et al. (eds.), The New Common, https://doi.org/10.1007/978-3-030-65355-2_2 
Handelsblad, De Telegraaf, Nieuwsuur, RTL-nieuws, and the NOS have all been reporting on people who link the current COVID-19 crisis to 5G. In many of these MSM reports, people with affinity to conspiracy theories are portrayed alongside some contextual information-fact checking the information provided by the covid spiracists or explaining their behavior. In this chapter, I analyze public reactions on Twitter to those MSM reports. Below, I first provide some background on research on conspiracy theories and then show how people perceive the covid-spiracy theory reports in the mainstream media.

\section{Research on Conspiracy Theories}

Conspiracy theories can come in many guises, and, to their fundamental core, they are a set of beliefs that behind the societal curtains evil, malevolent groups are indoctrinating individuals and/or governing societies (Aupers 2012). In the last decade, scholarly attention for conspiracy theories (Aupers 2012; Douglas et al. 2019; Letort 2017; Locke 2009), and public support for such theories (Oliver and Wood 2014; Stempel et al. 2007) has risen.

These recent efforts have pointed out how much certain publics of Western societies actually believe in conspiracy theories (e.g., Oliver and Wood have shown that roughly one-quarter of the USA has an affinity with such theories) and point to two major factors that underlie beliefs in conspiracy theories. The first is that people are trying to make sense of the world they live in (Butter 2014; Grenier 1992; Popper 1945). As processes of individualization, globalization, and secularization rob people of their feelings of security, it is proposed that those who feel insecure are culturally rationalizing (Campbell 2015) and are trying to find the meaning and purpose of the things that are happening (Aupers 2012; Harambam and Aupers 2017).

The second factor in explaining affinity with conspiracy theories is modernday anti- institutionalism (Elchardus and De Keere 2013; Melley 2008). Because people no longer trust the institutional backbone of modern societies, politics, science, the media, and the judiciary system, they start relying on themselves for finding out the truth and explaining what is going on. 


\section{The Debate on Twitter}

In the wake of MSM reports on the covid-spiracy theory on Twitter, people have been speaking their minds about such reports. In the following section, I will discuss public reactions to six of those reports. ${ }^{2}$

Among those who do not adhere to covid-spiracy theories, reactions can be divided into two camps. The first camp ridicules those who believe in the conspiracy theories, for instance, by implying that these people's IQs need to be tested ${ }^{3}$ and that they are mentally deranged. ${ }^{4}$ One person mockingly asks "whether it would be worthwhile investigating the linkage between pizza Hawaii and the Coronavirus." 5 The second camp of opponents of the covidspiracy diverge in their reactions to the MSM reporting in that some argue that the MSM are doing a great job in reporting on and debunking of conspirational thinkers ${ }^{6}$ whilst others argue that the MSM have crossed the line in giving conspirational thinkers a platform. ${ }^{7}$

Conspirational thinkers' reactions can be divided into three overarching themes. The first is their expressed concern about 5G technology and COVID-19. They argue against having a source of electromagnetic radiation in their proximity and draw parallels to the "proven" negative effects of electricity pylons, ${ }^{8}$ and they point to the danger that lies within the adaptation of $5 \mathrm{G}$ technology. ${ }^{9}$ Note, however, that the focus of these arguments concerns the danger of $5 \mathrm{G}$ technology. Secondly, the covid-spiracy theory supporters react strongly against the MSM reports that, in their view, are making a mockery of conspirational thinkers. They argue that the MSM are "demonizing the truth" and that those who are really looking for the truth are portrayed as

\footnotetext{
${ }^{2}$ Reactions to these six reports were included here: (1) Telegraaf: https://www.telegraaf.nl/ nieuws/715118123/weer-incident-bij-mast-verzet-5-g-wordt-militant, (2) Telegraaf: https://www. telegraaf.nl/nieuws/1762273884/complotdenkers-zien-verband-tussen-5-g-masten-en-corona?utm_ source=twitter\&utm_medium=social\&utm_campaign=seeding-telegraaf, (3) RTLNieuws: https://www. rtlnieuws.nl/editienl/laatste-videos-editienl/video/5118871/kritische-arts-gaat-viral?fbclid=IwAR0qwJH L1U7yNDdBD516H5bmtDLluO4L5StkckTi74KS8Q2WLYaKjBJFpM4, (4) NRC Handelsblad: https://www.nrc.nl/nieuws/2020/04/19/nana-denkt-dat-de-overheid-ons-uitdunt-met-5g-tijdens-corona-a3997217, (5) NOS: https://nos.nl/artikel/2330065-brand-bij-vier-zendmasten-heel-sterkvermoeden-van-brandstichting.html, and (6) Nieuwsuur: https://www.youtube.com/watch?v=RMuMB GaHttM\&feature=youtu.be

${ }^{3}$ https://twitter.com/terpGer/status/1252271787578097664

${ }^{4} \mathrm{https} / / /$ twitter.com/GJPvWesten/status/1248623467580125185

${ }^{5}$ https://twitter.com/joyce_devivre/status/1252151070127726592

${ }^{6}$ https://twitter.com/Genverbrander10/status/1252007731323494400

${ }^{7}$ https://twitter.com/knillis/status/1252259095320637442

${ }^{8}$ https://twitter.com/Kaasschaaf351/status/1248688462166994944

${ }^{9} \mathrm{https} / / /$ twitter.com/esmeraldaed/status/1248990551980027906
} 
"nutcases"10 and that those who merely ask questions are being attacked unjustly. ${ }^{11}$ In addition, they complain that MSM reports are rude and too generalizing and they state that they should be "falsely accusing their own mothers." ${ }^{2}$ Hence, it is safe to conclude that, in their eyes, the MSM are doing a particularly poor job. Thirdly and related to the foregoing, they state that the MSM are "slaves of the elite,"13,14 fully in line with the "current dictatorship of leftist political correctness" and dependent on a "dictatorial state" 15 or on Bill Gates. ${ }^{16}$ They argue that "in view of the growing opposition pushing the introduction of $5 \mathrm{G}$ could be called militant" 17 and others argue that there is just too little militancy in our country ${ }^{18}$ — suggesting that demolishing a $5 \mathrm{G}$ antenna should be seen as a promising start of rising up against the elites.

\section{Conclusion}

From my short and anecdotal discussion of responses to MSM reporting about the association between COVID-19 and 5G, it becomes clear that there are a lot of constants in the societal debates, which also thrived before the COVID-19 crisis started (Aupers 2012; Melley 2008). The first is that the MSM's attention to conspirational thinkers who link the current COVID-19 crisis to $5 \mathrm{G}$ does not cause these conspirational thinkers to trust the MSM more. If anything, the attention paid by the MSM seems to cause more distrust. The more attention they pay to it, as they are doing it now, the more critical people with strong affinities with conspiracy theories will become. This reflects recent scholarship that suggests that a "rational" and balanced approach to conspiracy theories can be compared to pouring water on a grease fire (Palmer 2018).

The second is the anti-institutional perspective, which not only seems to affect the covid-spiracy supporters' reactions but also the reactions of those

\footnotetext{
${ }^{10} \mathrm{https} / /$ twitter.com/paulrikmans/status/1259762911951683584

${ }^{11}$ https://twitter.com/IvoValkenburg/status/1259910435228332034

${ }^{12}$ https://twitter.com/VolkersBram/status/1259090705013669888

${ }^{13} \mathrm{Ibid}$.

${ }^{14} \mathrm{https} / /$ twitter.com/Protect_Nation/status/1260515202207973376

${ }^{15} \mathrm{https} / / /$ twitter.com/reiniertweet/status/1259166954213928960

${ }^{16}$ https://twitter.com/Complot_Denker/status/1259910360980750337

${ }^{17} \mathrm{https} / / /$ twitter.com/Verzet_Exit/status/1248732344544100358

${ }^{18} \mathrm{https} / /$ twitter.com/My_Name_Nobody_/status/1248842665115955201
} 
who do not adhere to the theory. On both sides of the isle, people are critical to MSM reports, albeit for different reasons. Those with more affinity with the covid-spiracy link their rather critical view about the media to larger antiinstitutionalist worldviews and see the victimization and demonization of conspirational thinkers portrayed in the MSM reports as a consequence of the media's servitude to a corrupt and dictatorial elite. This suggests that the same mechanisms that underlie affinity with other conspiracy theories are at work here too. People try to make sense of what is going on (Aupers 2012) and combine it with an almost inflammatory anti-institutionalism (Melley 2008). In this sense, this covid-spiracy theory may be nothing but a theory based on the same mechanisms. Like old wine in new barrels.

\section{References}

Aupers S (2012) 'Trust no one': modernization, paranoia and conspiracy culture. Eur J Commun 27(1):22-23. https://doi.org/10.1177/0267323111433566

Butter M (2014) Plots, designs, and schemes: American conspiracy theories from the puritans to the present, 1st edn. De Gruyter, Boston

Campbell C (2015) Easternization of the West: a thematic account of cultural change in the modern era. Routledge, London

Douglas KM, Uscinski JE, Sutton RM, Cichocka A, Nefes T, Ang CS, Deravi F (2019) Understanding Conspiracy Theories. Polit Psychol 40:3-35

Elchardus M, De Keere K (2013) Social control and institutional trust: Reconsidering the effect of modernity on social malaise. Soc Sci J 50(1):101-111. https://doi. org/10.1016/j.soscij.2012.10.004

Grenier R (1992) On the trail of America’s paranoid class: Oliver Stone's JFK. Natl Int 27:76-84

Harambam J, Aupers S (2017) 'I am not a conspiracy theorist': relational identifications in the Dutch conspiracy milieu. Cult Sociol 11(1):113-129. https://doi. org/10.1177/1749975516661959

Letort D (2017) Conspiracy culture in Homeland (2011-2015). Media War Conflict 10(2):152-167. https://doi.org/10.1177/1750635216656968

Locke S (2009) Conspiracy culture, blame culture, and rationalisation. Sociol Rev 57(4):567-585. https://doi.org/10.1111/j.1467-954X.2009.01862.x

Melley T (2008) Brainwashed! Conspiracy theory and ideology in the postwar United States. New German Critique 103:145-164. https://doi.org/10.121 5/0094033x-2007-023

Oliver JE, Wood TJ (2014) Conspiracy theories and the paranoid style(s) of mass opinion. Am J Polit Sci 58(4):952-966 
Palmer R (2018) Trust in science is not the answer to conspiracies: it's throwing water on a grease-fire (Doctoral dissertation). Illinois, Urbana

Popper KR (1945) The open society and its enemies. G. Routledge \& sons, London Stempel C, Hargrove T, Stempel GH (2007) Media use, social structure, and belief in 9/11 conspiracy theories. J Mass Commun Quart 84(2):353-372

Open Access This chapter is licensed under the terms of the Creative Commons Attribution 4.0 International License (http://creativecommons.org/licenses/by/4.0/), which permits use, sharing, adaptation, distribution and reproduction in any medium or format, as long as you give appropriate credit to the original author(s) and the source, provide a link to the Creative Commons licence and indicate if changes were made.

The images or other third party material in this chapter are included in the chapter's Creative Commons licence, unless indicated otherwise in a credit line to the material. If material is not included in the chapter's Creative Commons licence and your intended use is not permitted by statutory regulation or exceeds the permitted use, you will need to obtain permission directly from the copyright holder.

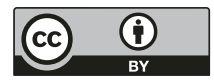

